\title{
Impact of operational factors on fossil energy inputs in motor-manual tree felling and processing: results of two case studies
}

\author{
Gh. Ignea, M.R. Ghaffaryian, S.A. Borz
}

Ignea Gh., Ghaffaryian M.R., Borz, S.A., 2017. Impact of operational factors on fossil energy inputs in motor-manual tree felling and processing: results of two case studies. Ann. For. Res. 60(1): 161-172.

Abstract. In many cases tree felling and processing operations are carried out motor-manually and knowledge about fossil fuel consumption and direct energy inputs when using such equipment is required for different purposes starting with operational costing and ending with environmental assessment of forest operations. In this study, fuel mixture, chain oil and direct fossil energy inputs were evaluated for two chainsaws which were used to fell and process trees in two silvicultural systems. The results of this study suggest that there is a strong dependence relation between selected tree size variables such as the diameter at breast height and tree volume on one hand and the fuel mixture, chain oil and direct fossil energy inputs when felling and processing broadleaved hardwood and resinous softwood trees on the other hand. For the broadleaved trees (mean tree volume of $1.50 \mathrm{~m}^{3}$ tree $^{-1}$, DBH of $45.5 \mathrm{~cm}$ and tree height of $21.84 \mathrm{~m}$ ) the mean direct fossil energy input was of $3.86 \mathrm{MJ} \mathrm{m}^{-3}$ while for resinous trees (mean tree volume of $1.77 \mathrm{~m}^{3}$ tree $^{-1}$, DBH of $39.28 \mathrm{~cm}$ and tree height of $32.49 \mathrm{~m}$ ) it was of $3.93 \mathrm{MJ} \mathrm{m}^{-3}$. Other variables, including but not limited to the technology used, work experience and procedural pattern, may influence the mentioned figures and extensive studies are required to clarify their effects. Keywords chainsaw, motor-manual felling and processing, direct fossil energy inputs, operational variables, selective cuttings, clear cuttings

Authors. Gheorghe Ignea, Stelian Alexandru Borz (stelian.borz@unitbv.ro) - Transilvania University of Braşov, Faculty of Silviculture and Forest Engineering, Department of Forest Engineering, Forest Management Planning and Terrestrial Measurements, Şirul Beethoven, no. 1, 500123, Braşov, Romania; Mohammad Reza Ghaffaryian, Forest Industries Research Centre, University of Sunshine Coast, Locked Bag 4, Maroochydore DC, Queensland, 4558, Australia.

Manuscript received September 15, 2016; revised November 17, 2016; accepted December 6, 2016; online first December 20, 2016. 


\section{Introduction}

In tree felling and processing operations, motor chainsaws still represent one of the main technical options, mainly due to affordable purchasing costs, possibility of use in terrains characterized by a wide gradient range, as well as due to a wide range of operational conditions related to the species and dimensions of trees to be harvested. In addition, recent research pointed out that such equipment may be characterized by an increased serviceability life (Calvo et al. 2013). However, the operation of such equipment requires a high level of professional training and may impede the workers' health when disregarding the work safety regulations by exposure to noise, vibrations and noxae (Tunay \& Melemez 2008). In particular, work safety procedures are to be strictly obeyed since work with such equipment may cause severe accidents (Lindroos \& Burström 2010) or even fatality.

At the same time, forest operations are cost driven activities, with their economic efficiency being directly affected by productive performance (Oprea \& Borz 2007), a reason that triggered numerous studies aiming to evaluate the time consumption and productivity in tree felling and processing operations using chainsaws (Wang et al. 2004, Ghaffariyan \& Shobani 2007, Balimunsi et al. 2012, Borz \& Ciobanu 2013, Ghaffariyan et al. 2013, Jourgholami et al. 2013). Similar to most product systems, timber harvesting supposes energy inputs which are provided to a significant extent by fossil resources, contributing this way to greenhouse gases (GHG) emissions in the environment (Markewitz 2006, Vusić et al. 2013). On the one hand, harvesting systems such as those coupling motor-manual felling and skidding are still under-investigated in terms of fossil energy inputs even if some progress has been made for some operational layouts and equipment (Picchio et al. 2009, Balimunsi et al. 2012, Maesano et al. 2013, Popovici 2013, Vusić et al. 2013). On the other hand, the results of such studies represent the computation basis in other kind of research 162 such as the life cycle assessment (Heinimann 2012).

In forest operations, the energetic analysis is one of the existing tools used to evaluate the energy needed for producing an output which may be either a service or a product. It covers both, the direct energy input representing the energy effectively used to sustain a process and the indirect energy input which stands for the energy stored in the materials used in the process (Vusić et al. 2013). While the energetic balance proved to be a good indicator characterizing the environmental performance of forest operations being adopted by many studies (Picchio et al. 2009, Magagnotti \& Spinelli 2011, Balimunsi et al. 2012, Ghaffariyan et al. 2012, Vusić et al. 2013), other impact types such as the soil disturbance or damage to residual trees may occur, involving sometimes economic losses (Dvořák \& Iordache 2010).

In forest operations, GHG emissions are generated by mechanical equipment with internal combustion engines. One way to reduce the GHG emissions when using chainsaws is to use bio-fuels and bio-oils. This comes as a result of no significant changes in the chainsaw performance induced by the use of mineral and bio-oils (Skoupy et al. 2010, Stanovský et al. 2013) while the bio-based fuels and lubricants have the advantage of a rapid degradation in the soil and lower ecotoxicity (Stanovský et al. 2013). Operational techniques used in motor-manual tree felling and processing affect the quantity of fuels and lubricant oils consumed during operations (Oprea 2008), therefore the direct energy inputs. In case of trees with a breast diameter ranging from 18 to 60 $\mathrm{cm}$ is recommended the use of a felling procedure consisting of an undercut and a backcut (Ciubotaru 1996), while trees of smaller dimensions may be felled using a single horizontal cut (Oprea 2008, Borz \& Ciobanu 2013). Also, in order to achieve the physical momentum needed by tree falling while keeping low the wood and fuels consumptions, it is recommended to make an undercut depth up to one third of the stump's diameter (Oprea 2008). These recommendations are the subject 
of procedural adaptation in the real operational conditions.

Methodologically, the measurement of direct fossil energy inputs in forest operations, is carried out using approaches specific to forest production studies. Depending on the intended goals, they can be carried out as energy consumption studies at different resolutions (Magagnotti \& Spinelli 2012). In particular, the development of empirical models aiming to describe relations between inputs, outputs and process variables are very useful when the performance assessment and behavior of an equipment (Visser \& Spinelli 2012) is in question. Elemental measurements carried out on a continuous basis are particularly useful when one tries to emphasize the effect of different work elements within the whole process. The results of such measurements are useful in process reengineering studies where, based on results yielded, decisions can be made on the exclusion, inclusion or improvement of a particular work element. However, there are some limitations when aiming to measure the fuel and lubricant consumption in motor-manual operations on an elemental basis. First of all, no sufficiently precise devices such as onboard flow meters may be used in real work conditions in order to get reliable data for an eventual elemental modeling scope. Then, when conducting a study at an elemental resolution, the researcher intervenes in the operator's way of work (Magagnotti \& Spinelli 2012), a fact that may affect other goals of the study such as the quantification of time consumption. This may be the reason for most of the studies carried out on motor-manual fuel and lubricants consumptions being done by considering wider scopes and assumptions. On the other hand, knowing how the operational patterns may affect the direct fossil energy inputs in motor-manual harvesting operations becomes important when dealing with issues such as economizing the energy and mitigating the environmental impact. Furthermore, in timber harvesting operations modeling studies play an important role and their results help the forest managers in decision making.
Nevertheless, the knowledge on what factors (operational variables) and to what extent they may affect the direct fossil energy input in motor-manual tree felling and processing operations is still limited.

The aim of this study was to evaluate the effect of operational factors on the direct energy inputs in motor-manual tree felling and processing operations. The objectives of this study were set to: (i) estimating the fuel and lubricant inputs in motor-manual tree felling and processing, (ii) identifying the relevant factors affecting the magnitude of such inputs and (iii) calculate the direct energy input from fossil resources based on conversion factors provided by existing literature.

\section{Material and methods}

\section{Study locations}

Field studies were carried out in two forest compartments (hereafter $A$ and $B$ ) located in the central part of Romania, in the administrative area of two forest districts. Motor-manual tree felling and processing was carried out in both forest compartments by a work team consisting of two men each, from which one was responsible of operating the chainsaw. In both forest compartments tree-length harvesting method was implemented, meaning that trees were felled, debranched (delimbed), topped and extracted to roadside using wheeled cable skidders. Two chainsaw units were used to fell and process the trees: a $3.4 \mathrm{~kW}$ Stihl 362 unit was used in compartment $A$ where the implemented sylvicultural system consisted of patched clearcuts, and a $3.6 \mathrm{~kW}$ Husqvarna 365 XP unit was used in compartment $B$ where the group shelterwood system was implemented.

\section{Data collection}

In each forest compartment, field data was collected by a team consisting of two-three 
researchers in February of 2014. In order to collect the data, an energy measurement study was designed and adapted to basic concepts regarding energy input measurement procedures described in Magagnotti \& Spinelli (2012). Fuel mixture $(F M C)$ and chain lubrication oil $(O C)$ inputs were directly measured for 18 and 17 felled and debranched (delimbed) trees in forest compartment $A$ and $B$ respectively, using different approaches. In compartment $A$, the chainsaw was fully refueled after each felled and delimbed tree. Consumption of fuel mixture $\left(F M C_{A}\right)$ and chain oil $\left(O C_{A}\right)$ in compartment $A$ were determined as the quantity of fuel mixture and chain oil used each time in order to fully refuel the fuel mixture and oil tanks after felling and processing a given tree. For this purpose, graded glass cylindrical recipients $( \pm 2 \mathrm{ml})$ were used, having a capacity of $250 \mathrm{ml}$ (Figure 1, Supporting Information). In felling area $B$, consumptions $\left(F M C_{B}\right.$ and $O C_{B}$ ) were measured separately for tree felling respectively tree debranching operations. During the field study, conventional gasoline and mineral oils were used for operations and a fuel mixture ratio of 25 oil to $975 \mathrm{ml}$ gasoline was used in both cases.

To check the impact of operational conditions on the fuel and oil consumption, several operational (independent) variables were collected in the field. Height of each tree $\left(H_{A}\right.$ respectively $H_{B}$ ) was measured at $10 \mathrm{~cm}$ accuracy using a timber measuring tape, after the tree felling operations (Figure 2, Supporting Information). Pruned height $\left(H P_{A}, H P_{B}\right)$ was measured using the same procedures. Stump $\left(S D_{A}, S D_{B}\right)$ and breast diameter $\left(D B H_{A}, D B H_{B}\right)$ were collected after and before tree felling using a forest caliper. Measurements were made to the nearest centimeter. In case of felling area $B$, additional variables were measured or observed such as the number of cuts involved by debranching each tree $(N C)$ and the diameter of each cut $(C D)$ as shown in Figure 3 (Supporting Information). Species $(S)$ of each felled and processed tree was noted. All the above data was recorded on a field book and transferred in digital form during the office 164 phase of the study.

\section{Data analysis}

Values of derived variables such as the tree volume $\left(T V_{A}, T V_{B}\right)$, cumulated diameter of cuts made in order to debranch each tree in compartment $B(C C D)$ and non-pruned height of each tree $\left(U P H_{A}, U P H_{B}\right)$ were obtained by computation in the office phase of study. Fuel mixture and chain lubrication oil inputs were computed by transforming the field recorded data from milliliters into kilograms, using the specific densities for normal conditions in case of gasoline and mineral oil. This transformational step was required for the calculation of direct fossil energy input. Direct fossil energy inputs due to fuel mixture $\left(E F M_{A}, E F M_{B}\right)$ and chain oil $\left(E O_{A}, E O_{B}\right)$ consumptions, as well as the total energy inputs $\left(T F E I_{A}, T F E I_{B}\right)$ were computed based on the conversion factors described by Biondi et al. (1989) respectively Volpi (1992) and referenced by Balimunsi et al. (2012) and Picchio et al. (2009) respectively. Volume of each felled and processed tree (TV) was estimated based on the allometric equations developed for Romanian conditions by Giurgiu et al. (2004) as a function of diameter at the breast height $(D B H)$, tree height $(T H)$ and tree species $(S)$. Cumulated diameter of cuts $(C C D)$ made in order to debranch the trees was calculated as the sum of all tree level measured $C D$ in compartment $B$. Statistical analysis was implemented for each measured or derived variable using procedures specific to work measurement such those described by Olsen et al. (1998), Magagnotti \& Spinelli (2012) as well as the general statistics such those described by Zar (1974). This involved a normality check of all the variables by the means of a Shapiro-Wilk statistic test, followed by the development of descriptive statistics, a co-linearity test using a correlation matrix analysis of the independent variables and a regression analysis which was carried out in order to develop fuel, oil and energy consumption models as a function of certain independent variables. A confidence level of 
$\alpha=0.01$ was assumed for all the carried-out tests and analyses. Data which did not follow a normal distribution was further described by median instead of mean. In the co-linearity tests an exclusion threshold set at $R=0.5$ has been adopted based on a Roemel-Orphal scale, as this procedure was accepted in similar studies (Sabo \& Poršinsky 2005). Regression models were developed by including all the possible independent variables into a maximal model based on logical reasons, followed by the exclusion of those being not relevant after significance analysis in a backward stepwise procedure using the same confidence level as described above. When two variables were strongly correlated and models could be developed by considering each one of them (for instance $S D$ versus $D B H$ ), separate models were developed based on each variable within the pair. Statistical analysis was carried out using MS Excel 2007 and Statistica 8.0 software packages.

\section{Results}

Dendrometric characteristics of the analyzed trees differed between the two studied forest compartments as shown in Table 1. Hardwood broadleaved trees (compartment $B$ ) were characterized by greater stump and breast diameters, but they presented lower heights at the sampling moment compared to trees sampled in compartment $A$ (softwood trees). In average, trees from compartment $B$ were naturally pruned only on about $16 \%$ of the total height, whereas the trees in compartment $A$ were pruned on about $45 \%$ of their height. However, the mean tree volume was quite similar in the two forest compartments due to the inclusion of wood contained in branches in case of compartment $B$ (Giurgiu et al. 2004). Felling a broadleaved tree having a stump diameter of about $61 \mathrm{~cm}$ (compartment $B$ ) required in average $50 \mathrm{ml}(0.037 \mathrm{~kg})$ of fuel mixture and $10 \mathrm{ml}(0.009 \mathrm{~kg})$ of chain oil (Table 1$)$. These figures include also the fuel mixture consumptions due to chainsaw starting before tree fell- ing as well as the fuel mixture combustion during the idle running of chainsaw. The median amounts of direct fossil energy inputs for felling a tree in compartment $B$ were of $2.05 \mathrm{MJ}$ coming from fuel mixture and $0.74 \mathrm{MJ}$ coming from chain oil, averaging 2.71 MJ (Table 1). On the other hand, in the same compartment, tree debranching required increased amounts of fuels, lubricants and fossil energy inputs if compared with tree felling, mainly due to a well-developed ramification of each analyzed tree (Table 1). In average, almost 11 cuts were required in order to fully debranch a tree while this parameter ranged from 6 to 17 cuts. The mean cumulated diameter of cuts $(75 \mathrm{~cm})$ was even greater than the mean stump diameter. In these conditions, the mean fuel mixture consumption required in order to fully debranch a tree was of $80 \mathrm{ml}(0.059 \mathrm{~kg})$, while the mean chain oil consumption averaged $20 \mathrm{ml}(0.018$ $\mathrm{kg}$ ) being two times greater than the amounts required by tree felling. Consequently, the fossil energy inputs were of $3.28 \mathrm{MJ}$ coming from fuel mixture and $1.49 \mathrm{MJ}$ coming from chain oil, accounting for a median value of $4.11 \mathrm{MJ}$ for tree debranching operations. Similar to tree felling operations, these numbers include also the fuel mixture consumptions due to chainsaw starting before tree debranching as well as fuel mixture combustion involved by chainsaw idle running. The total fossil energy input in tree felling and debranching operations averaged $6.93 \pm 4.92 \mathrm{MJ}$, ranging from 3.43 to 22.37 MJ (not shown in Table 1). Therefore, in order to fully fell and debranch the 17 studied trees with a total volume of $37.75 \mathrm{~m}^{3}$ from compartment $B, 145.82 \mathrm{MJ}$ of direct fossil energy input were required (energy consumption of $3.86 \mathrm{MJ} \mathrm{m}^{-3}$ ).

In comparison, felling and delimbing resinous trees (compartment $A$ ) having a mean stump diameter of about $51 \mathrm{~cm}$, a mean breast diameter of about $39 \mathrm{~cm}$, a mean height of about $32 \mathrm{~m}$ and a mean pruned height of about $15 \mathrm{~m}$ (Table 1) required, according to this study, in average $85 \mathrm{ml}(0.063 \mathrm{~kg})$ of fuel mixture and $46.72 \mathrm{ml}(0.042 \mathrm{~kg})$ of chain oil. Consequently, the fossil energy inputs were 
Table 1 Descriptive statistics of the operational conditions and energy inputs

\begin{tabular}{|c|c|c|c|c|c|}
\hline Parameter/variable & $\begin{array}{l}\text { Normality } \\
\text { pass }\end{array}$ & Min. & Max. & Range & $\begin{array}{l}\text { Mean/Median } \\
\text { (std. dev.) }\end{array}$ \\
\hline \multicolumn{6}{|l|}{ Compartment A } \\
\hline Stump diameter $\left[S D_{A}(\mathrm{~cm})\right]$ & Yes & 37.00 & 74.00 & 37.00 & $50.94(9.32)$ \\
\hline Breast diameter $\left[D B H_{A}(\mathrm{~cm})\right]$ & Yes & 29.00 & 50.00 & 21.00 & $39.28(6.05)$ \\
\hline Tree height $\left[T H_{A}(\mathrm{~m})\right]$ & Yes & 28.00 & 36.70 & 8.70 & $32.49(2.59)$ \\
\hline Pruned tree height $\left[P T H_{\mathrm{A}}(\mathrm{m})\right]$ & Yes & 11.30 & 19.00 & 7.70 & $14.68(2.10)$ \\
\hline Tree volume $\left[T V_{A}\left(\mathrm{~m}^{3}\right)\right]$ & Yes & 0.86 & 2.81 & 1.95 & $1.77(0.58)$ \\
\hline $\begin{array}{l}\text { Felling fuel mixture consumption } \\
{\left[F M C_{\text {A-felling\&delimbing }}(\mathrm{ml})\right]}\end{array}$ & Yes & 40.00 & 130.00 & 90.00 & $85.00(23.33)$ \\
\hline $\begin{array}{l}\text { Felling fuel mixture consumption } \\
{\left[F M C_{A \text {-felling\&delimbing }}(\mathrm{kg})\right]}\end{array}$ & Yes & 0.030 & 0.096 & 0.067 & $0.063(0.017)$ \\
\hline $\begin{array}{l}\text { Felling chain oil consumption } \\
{\left[O C_{\text {A-fellingeddelimbing }}(\mathrm{ml})\right]}\end{array}$ & Yes & 33.00 & 74.00 & 41.00 & $46.72(10.24)$ \\
\hline $\begin{array}{l}\text { Felling chain oil consumption } \\
{\left[O C_{\text {A-fellingeddelimbing }}(\mathrm{kg})\right]}\end{array}$ & Yes & 0.029 & 0.066 & 0.036 & $0.042(0.009)$ \\
\hline $\begin{array}{l}\text { Felling energy input from fuel mixture } \\
{\left[E F M_{\text {A-felling \&delimbing }}(\mathrm{MJ})\right]}\end{array}$ & Yes & 1.64 & 5.33 & 3.69 & $3.48(0.96)$ \\
\hline $\begin{array}{l}\text { Felling energy input from chain oil } \\
{\left[E O_{\text {A-felling\&delimbing }}(\mathrm{MJ})\right]}\end{array}$ & Yes & 2.46 & 5.51 & 3.05 & $3.48(0.76)$ \\
\hline $\begin{array}{l}\text { Total felling energy input - fossil fuels } \\
{\left[T E_{\text {A-felling gdelimbing }}(\mathrm{MJ})\right]}\end{array}$ & Yes & 4.25 & 10.84 & 6.59 & $6.96(1.62)$ \\
\hline \multicolumn{6}{|l|}{ Compartment B } \\
\hline Stump diameter $\left[S D_{B}(\mathrm{~cm})\right]$ & Yes & 38.00 & 97.00 & 59.00 & $60.97(6.59)$ \\
\hline Breast diameter $\left[D B H_{B}(\mathrm{~cm})\right]$ & Yes & 25.00 & 80.00 & 55.00 & $45.47(14.66)$ \\
\hline Tree height $\left[T H_{B}(\mathrm{~m})\right]$ & Yes & 15.00 & 26.50 & 11.50 & $21.84(3.23)$ \\
\hline Pruned tree height $\left[P T H_{B}(\mathrm{~m})\right]$ & No & 2.00 & 14.50 & 12.50 & $3.50^{\S}(3.12)$ \\
\hline Tree volume $\left[T V_{B}\left(\mathrm{~m}^{3}\right)\right]$ & No & 0.42 & 6.67 & 6.24 & $1.59^{\S}(1.64)$ \\
\hline No. of cuts (branching) $[\mathrm{NC}]$ & Yes & 6.00 & 17.00 & 11.00 & $10.88(3.26)$ \\
\hline Cumulated diameter of cuts $[C D C]$ & No & 34.50 & 391.00 & 356.50 & $74.50(106.53)$ \\
\hline $\begin{array}{l}\text { Felling fuel mixture consumption } \\
{\left[F M C_{B \text {-felling }}(\mathrm{ml})\right]}\end{array}$ & No & 20.00 & 136.00 & 116.00 & $50.00^{\S}(27.11)$ \\
\hline $\begin{array}{l}\text { Felling fuel mixture consumption } \\
{\left[F M C_{B-\text { felling }}(\mathrm{kg})\right]}\end{array}$ & No & 0.015 & 0.101 & 0.086 & $0.037^{\S}(0.020)$ \\
\hline Felling chain oil consumption $\left[O C_{B \text {-felling }}(\mathrm{ml})\right]$ & No & 3.00 & 27.00 & 24.00 & $10.00^{\S}(5.90)$ \\
\hline Felling chain oil consumption $\left[O C_{B \text {-felling }}(\mathrm{kg})\right]$ & No & 0.003 & 0.024 & 0.021 & $0.009^{\S}(0.005)$ \\
\hline $\begin{array}{l}\text { Felling energy input from fuel mixture } \\
{\left[E F M_{B \text {-felling }}(\mathrm{MJ})\right]}\end{array}$ & No & 0.82 & 5.57 & 4.75 & $2.05^{\S}(1.11)$ \\
\hline $\begin{array}{l}\text { Felling energy input from chain oil } \\
{\left[E O_{B \text {-felling }}(\mathrm{MJ})\right]}\end{array}$ & No & 0.22 & 2.01 & 1.79 & $0.74^{\S}(0.44)$ \\
\hline $\begin{array}{l}\text { Total felling energy input - fossil fuels } \\
{\left[T E_{B \text {-felling }}(\mathrm{MJ})\right]}\end{array}$ & No & 1.45 & 6.76 & 5.31 & $2.71^{\S}(1.38)$ \\
\hline $\begin{array}{l}\text { Branching fuel mixture consumption } \\
{\left[F M C_{B \text {-debranching }}(\mathrm{ml})\right]}\end{array}$ & No & 30.00 & 270.00 & 240.00 & $80.00^{\S}(64.13)$ \\
\hline $\begin{array}{l}\text { Branching fuel mixture consumption } \\
{\left[F M C_{B \text {-debranching }}(\mathrm{kg})\right]}\end{array}$ & No & 0.022 & 0.200 & 0.178 & $0.059^{\S}(0.018)$ \\
\hline $\begin{array}{l}\text { Branching chain oil consumption } \\
{\left[O C_{B \text {-debranching }}(\mathrm{ml})\right]}\end{array}$ & No & 10.00 & 61.00 & 51.00 & $20.00^{\S}(15.51)$ \\
\hline
\end{tabular}


Table 1 (Continuation)

\begin{tabular}{|c|c|c|c|c|c|}
\hline $\begin{array}{l}\text { Branching chain oil consumption } \\
{\left[O C_{B-\text { debranching }}(\mathrm{kg})\right]}\end{array}$ & No & 0.009 & 0.054 & 0.045 & $0.018^{\S}(0.014)$ \\
\hline $\begin{array}{l}\text { Branching energy input from fuel mixture } \\
{\left[E F M_{B-d e b r a n c h i n g}(\mathrm{MJ})\right]}\end{array}$ & No & 1.23 & 11.06 & 9.83 & $3.28^{\S}(2.63)$ \\
\hline $\begin{array}{l}\text { Branching energy input from chain oil } \\
{\left[E O_{B \text {-debranching }}(\mathrm{MJ})\right]}\end{array}$ & No & 0.74 & 4.54 & 3.80 & $1.49^{\S}(1.16)$ \\
\hline $\begin{array}{l}\text { Total branching energy input - fossil fuels } \\
{\left[T E_{B-\text { debranching }}(\mathrm{MJ})\right]}\end{array}$ & No & 1.97 & 15.61 & 13.63 & $4.11^{\S}(3.70)$ \\
\hline
\end{tabular}

Note. Values followed by ${ }^{\S}$ are the medians.

of $3.48 \mathrm{MJ}$ from fuel mixture and $3.48 \mathrm{MJ}$ from chain oil, averaging $6.96 \mathrm{MJ}$ for tree felling and delimbing operations (Table 1). The above-mentioned figures include also the fuel mixture, chain oil and energy consumptions due to starting and idle running of chainsaw. In the above described conditions the total fossil energy input in tree felling and delimbing operations averaged $6.96 \pm 1.62 \mathrm{MJ}$ (Table 1), ranging from 4.25 to $10.84 \mathrm{MJ}$. Therefore, in order to fully fell and delimb the 18 studied trees, having a total volume of $31.88 \mathrm{~m}^{3}$ from compartment $A, 125.33 \mathrm{MJ}$ of direct fossil energy input were required (energy consumption of $3.93 \mathrm{MJ} \mathrm{m}^{-3}$ ).

The mean fossil energy inputs $\left(\mathrm{MJ} \mathrm{m}^{-3}\right)$ were relatively similar even if the operational conditions differed substantially in the studied compartments (Table 1). However, the linear models shown in Figure 1 indicate that, as the breast diameter $(D B H)$ or tree volume $(T V)$ increases, the total fossil energy input $\left(T F E I_{A}\right.$, $T F E I_{B}$ ) will increase also, while its variation can be explained in proportions of 70-82\% $\left(R^{2}\right.$ $=0.70-0.82)$ by the selected independent variables. Nevertheless, the increment rates suggested in Figure 1 would be smaller in case of resinous trees, a fact that could be explained by several factors such as the reduced diameters of branches to be removed which were greater in case of broadleaved species (compartment $B)$.

The results of models developed to predict the fuel mixture, chain oil and fossil energy inputs at operational level are enclosed in Tables 2 and 3. For compartment $B$, models were developed to estimate the variation of aforemen- tioned variables as a function of stump diameter $\left(S D_{B}\right)$, breast diameter $\left(D B H_{B}\right)$, number of cuts $(N C)$ and the cumulated diameter of cuts $(C C D)$. Variation of fuel mixture consumption as well as of the energy input due to fuel mixture consumption when felling broadleaved trees $\left(F M C_{B \text {-felling }}, E F M_{B \text {-felling }}\right)$ were best explained by the stump diameter variation $\left(R^{2}\right.$ $=0.77)$, while the chain oil consumption and its associated energy input were explained in an improved proportion $\left(R^{2}=0.60\right)$ by variation of breast height diameter (Table 2) even if no plausible logical reasons were identified to support this fact. Total fossil energy input for felling operations $\left(T E_{B \text {-felling }}\right)$ was also explained in almost identical proportions by the stump diameter $\left(R^{2}=0.86\right)$ and breast height diameter $\left(R^{2}=0.89\right)$. For debranching operations (Table 2) it seems that the cumulated diameter of cuts $(C C D)$ explained in a greater proportion the variation of fuel mixture $\left(R^{2}=\right.$ $0.60)$ and chain oil $\left(R^{2}=0.79\right)$ as well as their associated fossil energy inputs and total energy expenditure $\left(R^{2}=0.68\right)$, even if relatively closer values of the determination coefficients were obtained also in the case of $N C$ predictor. This fact may be explained by a closer mechanical description of the process when using the diameters instead of number of cuts. However, the models developed as function of $N C$ and $C C D$ respectively have only a purely scientific value, because in practice such independent variables are less quantifiable in advance. Therefore, when estimating the amount of fossil fuels or direct fossil energy inputs for similar conditions one should use the models shown in Figure 1. All the independent varia- 

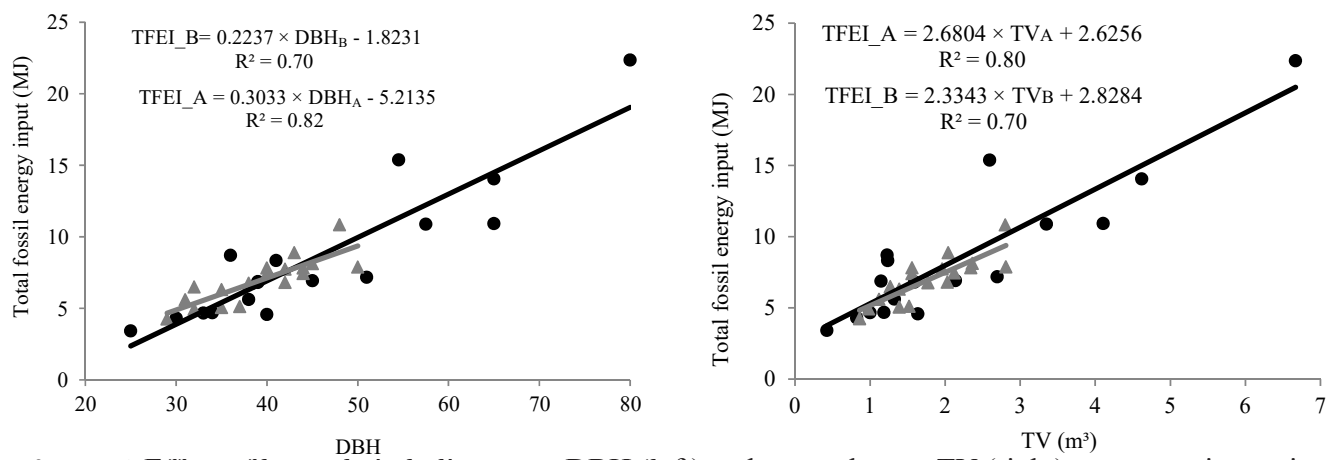

Figure 1 Effect of breast heigth diameter - DBH (left) and tree volume - TV (right) on energy inputs in the studied compartments

Table 2 Predictive linear models of fuel mixture, oil and energy inputs in tree felling and debranching operations - compartment B

\begin{tabular}{|c|c|c|c|c|c|}
\hline Linear model & $R^{2}$ & $F$ & Sig. $F$ & Predictor & $p$-value \\
\hline \multicolumn{6}{|l|}{ Tree felling operations, compartment B } \\
\hline$F M C_{B \text {-felling }}=1.4306 \cdot S D_{B}-34.46$ & 0.767 & 49.23 & $<0.001$ & $S D_{B}$ & $<0.001$ \\
\hline$F M C_{B \text {-felling }}=1.6026 \cdot D B H_{B}-20.11$ & 0.751 & 45.22 & $<0.001$ & $D B H_{B}$ & $<0.001$ \\
\hline$F M C_{B \text {-felling }}=0.0011 \cdot S D_{B}-0.026$ & 0.767 & 49.23 & $<0.001$ & $S D_{B}$ & $<0.001$ \\
\hline$F M C_{B \text {-felling }}=0.0012 \cdot D B H_{B}-0.015$ & 0.751 & 45.22 & $<0.001$ & $D B H_{B}$ & $<0.001$ \\
\hline$O C_{B \text {-felling }}=0.2467 \cdot S D_{B}-3.216$ & 0.481 & 13.92 & 0.002 & $S D_{B}$ & 0.002 \\
\hline$O C_{B \text {-felling }}=0.3106 \cdot D B H_{B}-2.299$ & 0.596 & 22.11 & $<0.001$ & $D B H_{B}$ & $<0.001$ \\
\hline$O C_{B \text {-felling }}=0.0002 \cdot S D_{B}-0.003$ & 0.481 & 13.92 & 0.002 & $S D_{B}$ & 0.002 \\
\hline$O C_{B \text {-felling }}=0.0003 \cdot D B H_{B}-0.002$ & 0.596 & 22.11 & $<0.001$ & $D B H_{B}$ & $<0.001$ \\
\hline$E F M_{B-\text { felling }}=0.0586 \cdot S D_{B}-1.412$ & 0.767 & 49.23 & $<0.001$ & $S D_{B}$ & $<0.001$ \\
\hline$E F M_{B-\text { felling }}=0.0657 \cdot D B H_{B}-0.824$ & 0.751 & 45.22 & $<0.001$ & $D B H_{B}$ & $<0.001$ \\
\hline$E O_{B-\text { felling }}=0.0184 \cdot S D_{B}-0.2400$ & 0.481 & 13.92 & 0.002 & $S D_{B}$ & 0.002 \\
\hline$E O_{B \text {-felling }}=0.0231 \cdot D B H_{B}-0.1710$ & 0.600 & 22.11 & $<0.001$ & $D B H_{B}$ & $<0.001$ \\
\hline$T E_{B-\text { felling }}=0.0770 \cdot S D_{B}-1.6510$ & 0.861 & 92.52 & $<0.001$ & $S D_{B}$ & $<0.001$ \\
\hline$T E_{B \text {-felling }}=0.0889 \cdot D B H_{B}-0.9950$ & 0.894 & 126.07 & $<0.001$ & $D B H_{B}$ & $<0.001$ \\
\hline \multicolumn{6}{|l|}{ Tree branching operations, compartment B } \\
\hline$F M C_{B \text {-debranching }}=13.854 \cdot N C-59.290$ & 0.495 & 14.72 & 0.002 & $N C$ & 0.002 \\
\hline$O C_{B-\text { debranching }}=3.8642 \cdot N C-18.050$ & 0.659 & 28.96 & $<0.001$ & $N C$ & $<0.001$ \\
\hline$F M C_{B \text {-dehranching }}=0.0103 \cdot N C-0.044$ & 0.495 & 14.72 & 0.002 & $N C$ & 0.002 \\
\hline$O C_{B-\text { debranching }}=0.0034 \cdot N C-0.016$ & 0.659 & 28.96 & $<0.001$ & $N C$ & $<0.001$ \\
\hline$E F M_{B-\text { debranching }}=0.5676 \cdot N C-2.429$ & 0.495 & 14.72 & 0.002 & $N C$ & 0.002 \\
\hline$E O_{B-\text { debranching }}=0.2879 \cdot N C-1.345$ & 0.659 & 28.96 & $<0.001$ & $N C$ & $<0.001$ \\
\hline$T E_{B-\text { debranching }}=0.8554 \cdot N C-3.774$ & 0.567 & 19.62 & $<0.001$ & $N C$ & $<0.001$ \\
\hline$F M C_{B \text {-debranching }}=0.4652 \cdot C C D+37.846$ & 0.597 & 22.23 & $<0.001$ & $C C D$ & $<0.001$ \\
\hline$O C_{B \text {-debranching }}=0.1292 \cdot C C D+9.110$ & 0.787 & 55.50 & $<0.001$ & $C C D$ & $<0.001$ \\
\hline$F M C_{B-\text { debranching }}=0.0003 \cdot C C D+0.028$ & 0.597 & 22.23 & $<0.001$ & $C C D$ & $<0.001$ \\
\hline$O C_{B \text {-debranching }}=0.0001 \cdot C C D+0.008$ & 0.787 & 55.50 & $<0.001$ & $C C D$ & $<0.001$ \\
\hline
\end{tabular}


Table 2 (continuation)

\begin{tabular}{llllll}
\hline$E F M_{B \text {-debranching }}=0.019 \cdot C C D+1.551$ & 0.597 & 22.23 & $<0.001$ & $C C D$ & $<0.001$ \\
\hline$E O_{B \text {-debranching }}=0.0100 \cdot C C D+0.679$ & 0.787 & 55.50 & $<0.001$ & $C C D$ & $<0.001$ \\
\hline$T E_{B \text {-debranching }}(\mathrm{MJ})=0.0287 \cdot C C D+2.229$ & 0.681 & 32.07 & $<0.001$ & $C C D$ & $<0.001$ \\
\hline
\end{tabular}

Note. Abbreviations: FMC - fuel mixture consumption, OC - lubrication oil consumption, EFM - energy input from fuel mixture, EO - energy input from lubrication oil, TE - total energy input.

Table 3 Predictive linear models of fuel mixture, oil and energy inputs in tree felling and delimbing operations - compartment $\mathrm{A}$

\begin{tabular}{|c|c|c|c|c|}
\hline Linear model & $R^{2}$ & $F$ & Sig. $F$ & $p$-value \\
\hline$F M C_{A-f e l l i n g \text { ded limbing }}=2.1125 \cdot S D_{A}-22.620$ & 0.713 & 39.66 & $<0.001$ & $<0.001$ \\
\hline$F M C_{A \text {-felling\&delimbing }}=3.4024 \cdot D B H_{A}-48.640$ & 0.778 & 56.06 & $<0.001$ & $<0.001$ \\
\hline$F M C_{A-\text { felling\&delimbing }}=34.8140 \cdot T V_{A}-23.341$ & 0.744 & 46.52 & $<0.001$ & $<0.001$ \\
\hline$O C_{\text {A-felling\&delimbing }}=0.7913 \cdot S D_{A}+6.4093$ & 0.519 & 17.23 & 0.001 & 0.001 \\
\hline$O C_{A-\text { felling\&delimbing }}=1.1316 \cdot D B H_{A}+2.2771$ & 0.446 & 12.89 & 0.002 & 0.002 \\
\hline$O C_{A-f e l l i n g d d e l i m b i n g}=12.1900 \cdot T V_{A}+25.1320$ & 0.473 & 14.37 & 0.002 & 0.002 \\
\hline$F M C_{A-\text { fellingtedelinbing }}=0.0016 \cdot S D_{A}+0.0170$ & 0.713 & 39.66 & $<0.001$ & $<0.001$ \\
\hline$F M C_{A-\text { fellingddelimbing }}=0.0025 \cdot \mathrm{DBH} H_{A}+0.0360$ & 0.778 & 56.06 & $<0.001$ & $<0.001$ \\
\hline$F M C_{A-f e l l i n g \& d e l i m b i n g}=0.0258 \cdot T V_{A}+0.0173$ & 0.744 & 46.52 & $<0.001$ & $<0.001$ \\
\hline$O C_{A-\text { fellingedelinbing }}=0.0007 \cdot S D_{A}+0.0057$ & 0.519 & 17.23 & 0.001 & 0.001 \\
\hline$O C_{A \text {-fellingtdelimbing }}=0.0010 \cdot D B H_{A}+0.0020$ & 0.446 & 12.89 & 0.002 & 0.002 \\
\hline$O C_{A-\text { felling\&delimbing }}=0.0108 \cdot T V_{A}+0.0224$ & 0.473 & 14.37 & 0.002 & 0.002 \\
\hline$E F M_{A-\text {-elling\&delimbing }}=0.0865 \cdot S D_{A}-0.9270$ & 0.713 & 39.66 & $<0.001$ & $<0.001$ \\
\hline$E F M_{\text {A-fellingldelimbing }}=0.1394 \cdot D B H_{A}-1.9930$ & 0.778 & 56.06 & $<0.001$ & $<0.001$ \\
\hline$E F M_{\text {A-felling\&delimbing }}=1.4262 \cdot T V_{A}+0.9562$ & 0.744 & 46.52 & $<0.001$ & $<0.001$ \\
\hline$E O_{\text {A-felling\&delimbing }}=0.0589 \cdot S D_{A}+0.4775$ & 0.519 & 17.23 & 0.001 & 0.001 \\
\hline$E O_{A-\text { felling\&delimbing }}=0.0843 \cdot D B H_{A}+0.1696$ & 0.446 & 12.89 & 0.002 & 0.002 \\
\hline$E O_{\text {A-felling\&delimbing }}=0.9081 \cdot T V_{A}+1.8722$ & 0.473 & 14.37 & 0.002 & 0.002 \\
\hline$T E_{\text {A-fellingedelimbing }}=0.1455 \cdot S D_{A}-0.4490$ & 0.704 & 37.98 & $<0.001$ & $<0.001$ \\
\hline$T E_{A-f e l l i n g \& d e l i m b i n g}=0.2237 \cdot D B H_{A}-1.823$ & 0.700 & 37.32 & $<0.001$ & $<0.001$ \\
\hline$T E_{\text {A-felling\&delimbing }}=2.3343 \cdot T V_{A}-2.8284$ & 0.696 & 36.70 & $<0.001$ & $<0.001$ \\
\hline
\end{tabular}

Note. Abbreviations: FMC - fuel mixture consumption, OC - lubrication oil consumption, EFM - energy input from fuel mixture, EO - energy input from lubrication oil, TE - total energy input.

bles were significant at the chosen confidence level $\alpha=0.01$ (Table 2). Fuel mixture consumption when felling and delimbing resinous trees as well as its associated energy input (Table 3), were significantly dependent on $D B H$ $\left(R^{2}=0.78\right)$ and tree volume $\left(R^{2}=0.74\right)$ while the chain oil consumption and its associated energy input were highly correlated with the stump's diameter $\left(R^{2}=0.52\right)$. However, the variation of total fossil energy input $\left(T E_{A-\text { fell- }}\right.$ ing\&delimbing) was explained in almost equal proportions by the variation of all the analyzed predictors $\left(R^{2}=0.70\right)$.

\section{Discussion}

Unfortunately, no effective comparisons can 
be made due to the different operational conditions between this study and other reported results. Such conditions rest in differences between the operational layout, equipment used, nature of harvested trees and the operational conditions. However, some of the results reported by other studies are discussed herein relative to the results of this study. For instance, Picchio et al. (2009) studied the energy balance when harvesting oak trees in a coppicing system and they found out that the amount of direct energy input (machinery) caused by felling, extraction and transport of fire wood assortments was as high as 43.46-61.01 $\mathrm{GJ} \mathrm{ha}^{-1}$ for different bunching means such as mules, chutes and winches, in conditions in which all the harvested wood was extracted to landing by a $75 \mathrm{~kW}$ tractor and transported using a 16 $\mathrm{t}$ truck. In their study 377 trees $\left(177 \mathrm{~m}^{3}\right)$ were felled and fully processed from a one-hectare area. Such figures were explained by the advanced level of tree processing, the inclusion of all the operational stages from the standing tree to the end-user as well as by the consideration of human, animal and indirect energy inputs. Maesano et al. (2013) studied the energy inputs in logging operations in a tropical forest of Cameroon. In their study, $6.4 \mathrm{~kW}$ Stihl MS 880 units were used for felling and processing trees with diameters ranging from 80 to $150 \mathrm{~cm}$, process phases which accounted also for the greatest time share in tree felling operations. In the described conditions, they found out that the direct fossil energy inputs were, in average, as high as $48.7 \mathrm{MJ} \mathrm{m}^{-3}$. This figure probably covered the tree felling and debranching even if not explicitly described. Therefore, the obvious difference in the direct energy expenditure reported by them and that reported by this study may be the result of equipment used and the characteristics of harvested trees.

Balimunsi et al. (2012) included in their study an energy balance of tree felling and processing operations carried out in two forest compartments where resinous species were extracted. They analyzed the direct energy input (machinery and manpower) required by tree 170 felling, delimbing and bucking carried out by a $2.3 \mathrm{~kW}$ chainsaw in average conditions characterized by a tree volume of $0.69-0.78 \mathrm{~m}^{3}$ tree $^{-1}$, a tree height of $17 \mathrm{~m}$, a mean breast diameter of $26 \mathrm{~cm}$, and about 3.5 cross-cuttings made per tree in order to recover the logs. They found out that an energy input of $19 \mathrm{MJ} \mathrm{m}^{-3}$ was required for tree felling, delimbing and bucking when dealing with non-pruned trees of which about $10 \mathrm{MJ} \mathrm{m}^{-3}$ were associated with delimbing and bucking. Furthermore, they reported that about $17 \mathrm{MJ} \mathrm{m}^{-3}$ were required for tree felling, delimbing and bucking when dealing with pruned trees of which $8.63 \mathrm{MJ} \mathrm{m}^{-3}$ were associated with tree felling. However, these figures included also the direct energy input related to manpower, in conditions in which a full felling and processing work cycle took about 10 minutes in each of the studied felling areas.

Therefore, the lower energy expenditures yielded by this study may be explained in several ways. First of all, in this study only tree felling and delimbing (debranching) operations were carried out, hence excluding the fossil energy expenditure which otherwise would be involved by tree bucking as other studies reported (Picchio et al. 2009, Balimunsi et al. 2012). In addition, the results of this study included only the direct fossil energy input, and no assumptions were made on the manpower direct energy inputs nor on the indirect energy inputs. The equipment used may have significant effects on the variation in energy inputs but heavier chainsaws are typically used when harvesting larger trees. Nevertheless, when dealing with very large trees and such chainsaws are not available, the use of regular ones may involve quite different felling and processing procedures (Oprea 2008), probably increasing the direct energy inputs in tree felling and processing operations. In addition, tree felling may involve an operational organization that can be more complex compared to that reported by this study as a result of tree characteristics. While being specific to very old trees, work elements such as cutting down the buttress roots (Ghaffariyan \& 
Shobani 2007) may add a significant amount of direct energy input to the regular one. Furthermore, the work experience and operational habits are known factors affecting the productive performance in forest operations. This is important as the chainsaw is kept idling in a significant proportion of the operational time. Therefore, a higher operational pace can contribute to the reduction of direct fossil energy inputs but it will be more physically demanding for the workers. Nevertheless, most of the existing studies are observational and address particular conditions. From this point of view, studies should be carried out to better understand how a wider range of operational factors and equipment types may affect the energy requirements in such operations. As indicated by the energy inputs prediction models, the larger the tree size the higher the energy inputs per tree. However, this behavior is specific to the studied range because, for the same equipment type and work team, smaller trees may involve simpler felling procedures (Borz \& Ciobanu 2013) while larger trees may require more complicated ones (Ghaffariyan \& Shobani 2007, Oprea 2008). Environmental temperature may affect the combustion process respectively fuel consumption when using chainsaws which can be studied further. Also, separations between idle running and loaded running of chainsaw are difficult to make, even if their shares of participation may affect the shape of developed models. Nevertheless, the results presented in this paper may be of use in predicting fuel consumption in felling and processing operations carried out under similar operating conditions.

\section{Conclusions}

This study aimed to estimate the direct energy inputs in motor-manual tree felling and processing operations under the assumption of using the tree length harvesting method. The results indicate that the direct fossil energy inputs in tree felling and processing operations depend on $D B H$ and the tree volume, the lat- ter being the most used predictors in such research.

While no particularly high differences were found in terms of mean direct fossil energy inputs between the two studied cases, the direct energy inputs associated with tree processing operations were higher as demonstrated by the second case study. Also, there was an order of magnitude characterizing the energy inputs of tree feeling and processing as the developed models indicated differences between the broadleaved and coniferous trees. However, this effect cannot be exclusively attributed to the species group as the broadleaved trees had a poor pruning condition in this study.

\section{Acknowledgements}

We would like to thank Mrs. Eng. Elena Catişov, Mrs. Eng. Alina Neagu, Mr. Eng. Laurenţiu Vişan, Mr. Eng. Nicolae Talagai, Mr. Eng. Daniel Şerban, and Mr. Eng. Andrei Apăfăian for their valuable support and participation in data collection activity. Also, we would like to thank the managers of R.P.L.P. Kronstadt Braşov and State Forest District of Sighişoara for their support during data collection, as well as to the harvesting companies personnel which allowed us to make this study.

\section{References}

Balimunsi H., Grigolato S., Picchio R., Nyombi K., Cavalli R., 2012. Productivity and energy balance of forest plantation harvesting in Uganda. Forestry Studies in China 14 (4): 276-282. DOI: 10.1007/s11632-0120404-y

Biondi P., Parano V., Pellizzi G., 1989. La richieste d'energia del sistema agricolo italiano [The energy requirements of the Italian agricultural system]. Progetto finalizzato energetic, $79 \mathrm{p}$.

Borz S.A., Ciobanu V.D., 2013. Efficiency of motor-manual felling and horse logging in small-scale firewood production. African Journal of Agricultural Research 8 (24): 3126-3135.

Calvo A., Manzone M., Spinelli R., 2013. Long term repair and maintenance cost of some professional chainsaws. Croatian Journal of Forest Engineering 34 (2): 265-272.

Dvořák J., Iordache E., 2010. Estimating the level of trees 
damages and financial losses by logging. Bulletin of the Transilvania University of Braşov 3(52): 37-46.

Ghaffariyan M.R., Naghdi R., Ghajar I., Nikooy M., 2013. Time prediction models and cost evaluation of cut-tolength (CTL) harvesting method in a mountainous forest. Small Scale Forestry 12: 181-192. DOI: 10.1007/ s11842-012-9204-4

Ghaffariyan M.R., Sessions J., Brown M., 2012. Evaluating productivity, cost, chip quality and biomass recovery for a mobile chipper in Australian road side chipping operations. Journal of Forest Science 58 (2): 530-535.

Ghaffaryian M.R., Shobani H., 2007. Cost production study of motor-manual felling and processing of logs. Forest Science 3: 69-76.

Ciubotaru A., 1996. Exploatarea pădurilor [Forest harvesting]. Lux Libris Publishing House, Braşov, 351 p.

Giurgiu V., Decei I., Drăghiciu D., 2004. Metode şi tabele dendrometrice [Dendrometrical methods and tables]. Ceres Publishing House, Bucharest, 575 p.

Heinimann H.R., 2012. Life cycle assessment in forestry - State and perspectives. Croatian Journal of Forest Engineering 33 (2): 357-372.

Jourgholami M., Majnounian B., Zargham N., 2013. Performance, capability and costs of motor-manual tree felling in Hyrcanian hardwood forest. Croatian Journal of Forest Engineering 34 (2): 283-293.

Lindroos O., Burström L., 2010: Accident rates and types among self-employed private forest owners. Accident Analysis and Prevention 42: 1729-1735. DOI: 10.1016/j.aap.2010.04.013

Maesano M., Picchio R., Lo Monaco A., Neri F., Lasserre B., Marchetti M., 2013. Productivity and energy consumption in logging operation in a Cameroonian tropical forest. Ecological Engineering 57: 149-153. DOI: 10.1016/j.ecoleng.2013.04.013

Magagnotti N., Spinelli R., 2011. Financial and energy cost of low-impact wood extraction in environmentally sensitive areas. Ecological Engineering 37 (4): 601606. DOI: 10.1016/j.ecoleng.2010.12.021

Magagnotti N., Spinelli R., (Eds.) 2012. COST Action FP0902 - Good practice guideline for biomass production studies. CNR IVALSA, Florence, Italy, $41 \mathrm{p}$.

Markewitz D., 2006. Fossil fuel carbon emissions from silviculture: Impacts on net carbon sequestration in forests. Forest Ecology and Management 236: 153-161. DOI: $10.1016 /$ j.foreco.2006.08.343

Olsen E., Hossain M., Miller M., 1998. Statistical comparison of methods used in harvesting work studies. Oregon State University, Forest Research Laboratory, Corvallis, OR. Research Contribution no. 23, 31p.

Oprea I., 2008. Tehnologia exploatării lemnului [Timber harvesting technology]. Transilvania University Press, Braşov, 273 p.

Oprea I., Borz S.A., 2007. Organizarea şantierului de exploatare a lemnului [Organization of timber harvesting sites]. Transilvania University Press, Braşov, 133 p.

Picchio R., Maesano M., Savelli S., Marchi E., 2009. Pro- ductivity and energy balance in conversion of a Quercus cerris L. coppice stand into high forest in Central Italy. Croatian Journal of Forest Engineering 30 (1): 15-26.

Popovici R., 2013. Estimating chainsaw operating costs based on fuels, lubricants and spare parts. Bulletin of the Transilvania University of Braşov 6(55): 63-68.

Sabo A., Poršinsky T., 2005. Skidding of fir roundwood by Timberjack 240C from selective forests of Gorski Kotar. Croatian Journal of Forest Engineering 26 (1): 13-27.

Skoupy A., Klvac R., Hosseini S., 2010. Changes in the external speed characteristics of chainsaw engines with the use of mineral and vegetable oils. Croatian Journal of Forest Engineering 31(2): 149-155.

Stanovský M., Schürger J., Jankovský M., Messingerová V., Hnilica R., Kučera M., 2013. The effect of lubricating oil on temperature of chainsaw cutting system. Croatian Journal of Forest Engineering 34(1): 83-90.

Tunay M., Melemez K., 2008. Noise induced hearing loss of forest workers in Turkey. Pakistan Journal of Bilogical Sciences 11 (17): 2144-2148. DOI: 10.3923/ pjbs.2008.2144.2148

Visser R., Spinelli R., 2012. Determining the shape of the productivity function for mechanized felling and felling-processing. Journal of Forest Research 17: 397-402. DOI: $10.1007 / \mathrm{s} 10310-011-0313-2$

Volpi R., 1992. Bilanci energetici in agricoltura (Energy balance in agriculture). Laruffa Editore, Reggio Calabria.

Vusić D., Šušnjar M., Marchi E., Spina R., Zečić Z., Picchio R., 2013. Skidding operations in thinning and shelterwood cut of mixed stands - Work productivity, energy inputs and emissions. Ecological Engineering 61: 216-223. DOI: 10.1016/j.ecoleng.2013.09.052

Zar J.H., 1974. Biostatistical analysis, Englewood Cliffs, USA, Prentice Hall Inc.

Wang J., Long C., McNeel J., Baumgras J., 2004. Productivity and cost of manual felling and cable skidding in Central Appalachian hardwood forests. Forest Products Journal 54 (12): 45-51.

\section{Supporting Information}

The online version of the article includes Supporting Information:

Figure 1. Measurement of fuel mixture and chain oil consumption in compartment B

Figure 2. Measurement of tree height in compartment $\mathrm{A}$

Figure 3. Measurement of cuts diameters in compartment B 